\title{
Upper crustal structure of Deception Island area (Bransfield Strait, Antarctica) from gravity and magnetic modelling
}

\author{
A. MUÑOZ-MARTÍN ${ }^{1 *}$, M. CATALÁN² ${ }^{2}$ J. MARTÍN-DÁVILA² and A. CARBÓ1 \\ ${ }^{1}$ Departamento de Geodinámica, Facultad de Geología, Universidad Complutense, Madrid 28040, Spain \\ ${ }^{2}$ Real Instituto y Observatorio de la Armada, San Fernando 11100 (Cádiz), Spain \\ *Corresponding author: amunoz@geo.ucm.es
}

\begin{abstract}
Deception Island is a young, active volcano located in the south-western part of Bransfield Strait, between the Antarctic Peninsula and the South Shetland archipelago. New gravity and magnetic data, from a marine geophysical cruise (DECVOL-99), were analysed. Forty-eight survey lines were processed and mapped around Deception Island to obtain Bouguer and magnetic anomaly maps. These maps show welldefined groups of gravity and magnetic anomalies, as well as their gradients. To constrain the upper crustal structure, we have performed $2+1 / 2 \mathrm{D}$ forward modelling on three profiles perpendicular to the main anomalies of the area, and taking into account previously published seismic information. From the gravity and magnetic models, two types of crust were identified. These were interpreted as continental crust (located north of Deception Island) and more basic crust (south of Deception Island). The transition between these crustal types is evident in the Bouguer anomaly map as a high gradient area trending NE-SW. Both magnetic and gravity data show a wide minimum at the eastern part of Deception Island, which suggests a very low bulk susceptibility and low density intrusive body. With historical recorded eruptions and thermal and fumarolic fields, we interpret this anomaly as a partially melted intrusive body. Its top has been estimated to be at $1.7 \mathrm{~km}$ depth using Euler deconvolution techniques.
\end{abstract}

Received 10 May 2004, accepted 3 November 2004

Key words: Euler deconvolution, gravity and magnetic anomalies, marine survey, potential field modelling

\section{Introduction}

Deception Island forms the emergent part of a young active shield volcano (less than $1 \mathrm{Ma}$ ). It lies in the south-western part of Bransfield Strait between the Antarctic Peninsula and the South Shetland archipelago (Figs 1 \& 2). In December 1999 a marine geophysical survey was carried out around and within (Port Foster) the island (Fig. 3). Bathymetry, gravity field and magnetic data were obtained using the Spanish Polar RV Hespérides. The campaign relied on previously available good quality potential field data from the Deception Island geographical framework. Previously published works (Grad et al. 1992, 1997) used seismic refraction to obtain a general picture of Deception Island upper crustal structure. In this paper, this information was used as a starting point and more detail added by incorporating locally acquired potential field information $(2+1 / 2 \mathrm{D}$ forward gravity and magnetic modelling along three profiles). Potential field forward modelling looks at the crust from two independent points of view, i.e. its magnetic and its density properties. By incorporating further sources of information such as seismic refraction and geology, it should be possible to delineate geometric structures with increased confidence. This improves our knowledge of tectonics and volcanic processes in the study area.

\section{Geological setting}

Bransfield Strait is a $500 \mathrm{~km}$ long extensional basin, with a well-marked NE-SW orientation that developed during the Late Cenozoic, which ends abruptly towards the south-west. The Hero fracture zone marks this limit, whereas the northeast limit is more gradual (Southern Scotia plate) (González-Casado et al. 2000, Figs 1 \& 2). The Bransfield Strait is considered to be a backarc basin of the South Shetland Islands volcanic arc (Fig. 1). The origin of this archipelago is related to magmatism and deformation induced by Phoenix plate subduction under the Antarctic plate during the upper Mesozoic-Cenozoic interval (Dalziel 1984, Barker et al. 1991). This convergence ceased 3.3 Ma ago when the Phoenix plate's spreading became inactive (Aluk Ridge, Fig. 1) (Lawver et al. 1995, Livermore et al. 2000). Bransfield Strait's origin is a matter of debate; two main hypotheses are given:

a) Its formation is related to "roll-back" of the South Shetland trench, which in turn produced northwestward migration of the South Shetland archipelago (Smellie et al. 1984, Maldonado et al. 1994, Lawver et al. 1995, 1996).

b) The NW-SE extension of the Bransfield Strait is related to the Scotia vs Antarctic plate transtensional regime, all along the South Scotia ridge (González- 


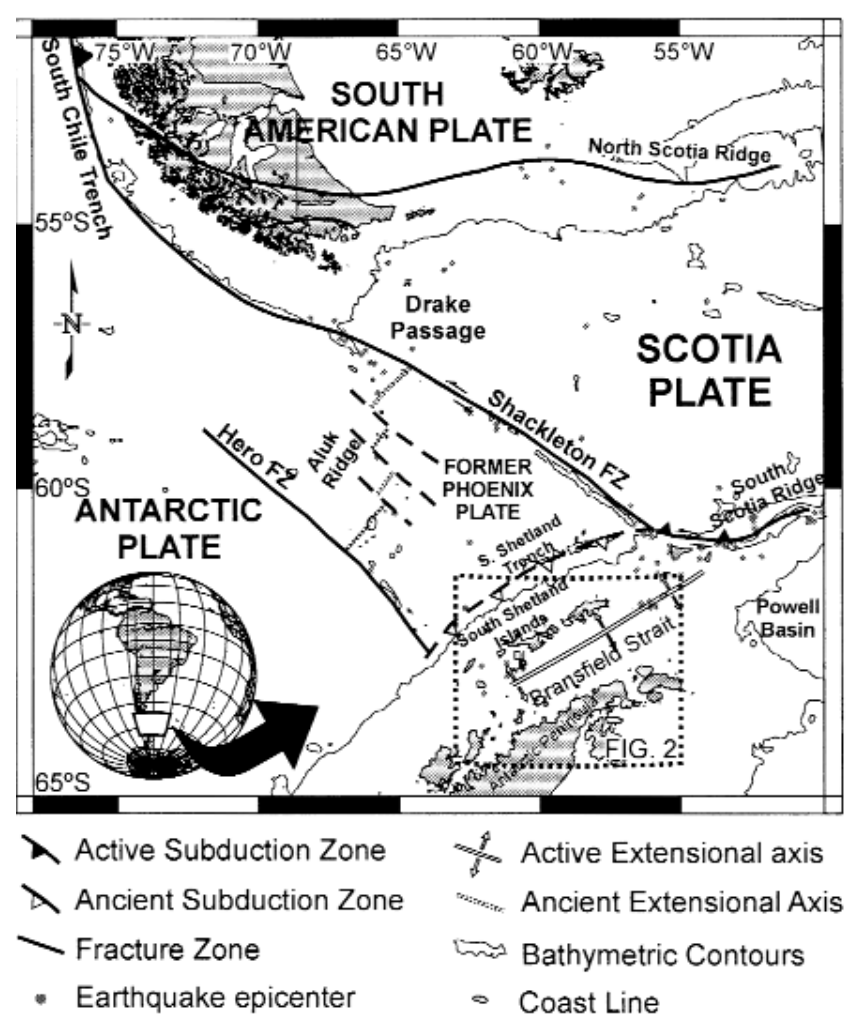

Fig. 1. Geographical and tectonic setting for the study area. Global bathymetry (Smith \& Sandwell 1997) is shown (contour lines every 2500 m). Epicenters from Engdahl et al. (1998) database.

\section{Casado et al. 2000, Giner-Robles et al. 2003).}

This area has been the subject of several geophysical and geological investigations, in particular seismic reflection (Acosta et al. 1992, Barker \& Austin 1994, Prieto et al. 1998), magnetics (Roach 1978), tectonics (Gràcia et al. 1996, 1997, González-Casado et al. 1999b, Baraldo \& Rinaldi 2000), seismo-tectonics (Pelayo \& Wiens 1989, Ibáñez et al. 2000), wide-angle seismic (Grad et al. 1992, 1997, Barker et al. 2003) and airborne gravity (Garrett 1990).

For gravity and magnetic modelling special consideration must be given to previous seismic refraction works. Grad et al. (1992) described the results of seismic refraction investigations on the upper crustal structure in the Deception Island area, and Grad et al. (1997) extended these studies all along Bransfield Strait central axis. Those previous, cited works are of twofold interest for forward modelling: to locate main seismic discontinuities (crustal structure); and to provide seismic velocities that could be correlated with densities (Ludwig et al. 1970). Besides marine geophysical studies, gravity and magnetic surveys have been performed on Livingston and Deception islands, where several gravity stations were established (Ortiz et al. 1992). These gravity stations (Fig. 3) allow linkage between marine gravity data and the Argentinian gravity net (Ushuaia). Recent stratigraphic studies on Deception Island
(Baraldo \& Rinaldi 2000, Smellie et al. 2002) have provided bulk magnetic susceptibilities analyses that have been useful for our magnetic modelling.

\section{Gravity and magnetic acquisition and data processing}

The marine geophysical campaign was planned as a systematic survey, and the track lines were parallel and equidistant. Control lines, perpendicular to the main track line circuit, were also set down. Two different situations were well established: inside and outside Deception Island. To accomplish this, two different parameter sets needed to match.

a) External survey. Track line courses were set perpendicular to the main morphostructural directions at Bransfield Strait. The main course of the surveillance track lines was $\mathrm{N} 125^{\circ} \mathrm{E}$, and for control lines was $\mathrm{N} 40^{\circ} \mathrm{E}$. Across track distance varied from 1 to $3 \mathrm{~km}$ (Fig. 3)

b) Port Foster. Track course inside Deception Island was determined by safe ship operations and hydrographic surveying, which must fulfil strict requirements. The main survey track lines' course was $\mathrm{N} 160^{\circ} \mathrm{E}$, and $\mathrm{N} 110^{\circ} \mathrm{E}$ for control lines, except one line that was oriented $\mathrm{N} 20^{\circ} \mathrm{E}$. Across track distance varied from 200 to $400 \mathrm{~m}$ (Fig. 3b).

\section{Gravity data processing}

At sea, a BRGM-3 gravimeter was used with a $0.1 \mathrm{~Hz}$ sampling rate and $1 \mathrm{mGal}$ of precision. To avoid the trackiness effect and to homogenize the quality of the data at the survey area, a sub-sampling was performed, taking every four readings ( $200 \mathrm{~m}$ average distance). To minimize possible edge effects at Port Foster, a complementary survey was developed around the coastline, using a Lacoste \& Romberg mod. G gravimeter. This survey provided 33 readings, which were referred to the gravity Argentinian Base. Satellite-borne gravity data (Smith \& Sandwell 1997) were also used to avoid possible edge effects during interpolation. Gravity readings were linked to the international reference network by using the Argentinian gravity base $\mathrm{K}$ at Ushuaia ( $981468.72 \mathrm{mGal})$. Instrumental drift $(0.095 \mathrm{mGal} /$ day $)$, diurnal variation and Eötvös corrections were applied, and anomalies were referred to GRS67 ellipsoid. Water layer and sea-bottom terrain effects were extracted by using 2.67 and $1.03 \mathrm{~g} \mathrm{~cm}^{-3}$ on land and at sea, respectively. Sea-bottom terrain effect was calculated by using a $200 \mathrm{~m}$ grid at Port Foster and $1000 \mathrm{~m}$ grid at Bransfield Strait (Carbó et al. in press). To perform these corrections, a digital terrain model of Deception Island (1 km grid size) was merged with a topographic and gravity database (Smith \& Sandwell 1997), as well as with bathymetric data from the DECVOL campaign. To evaluate 


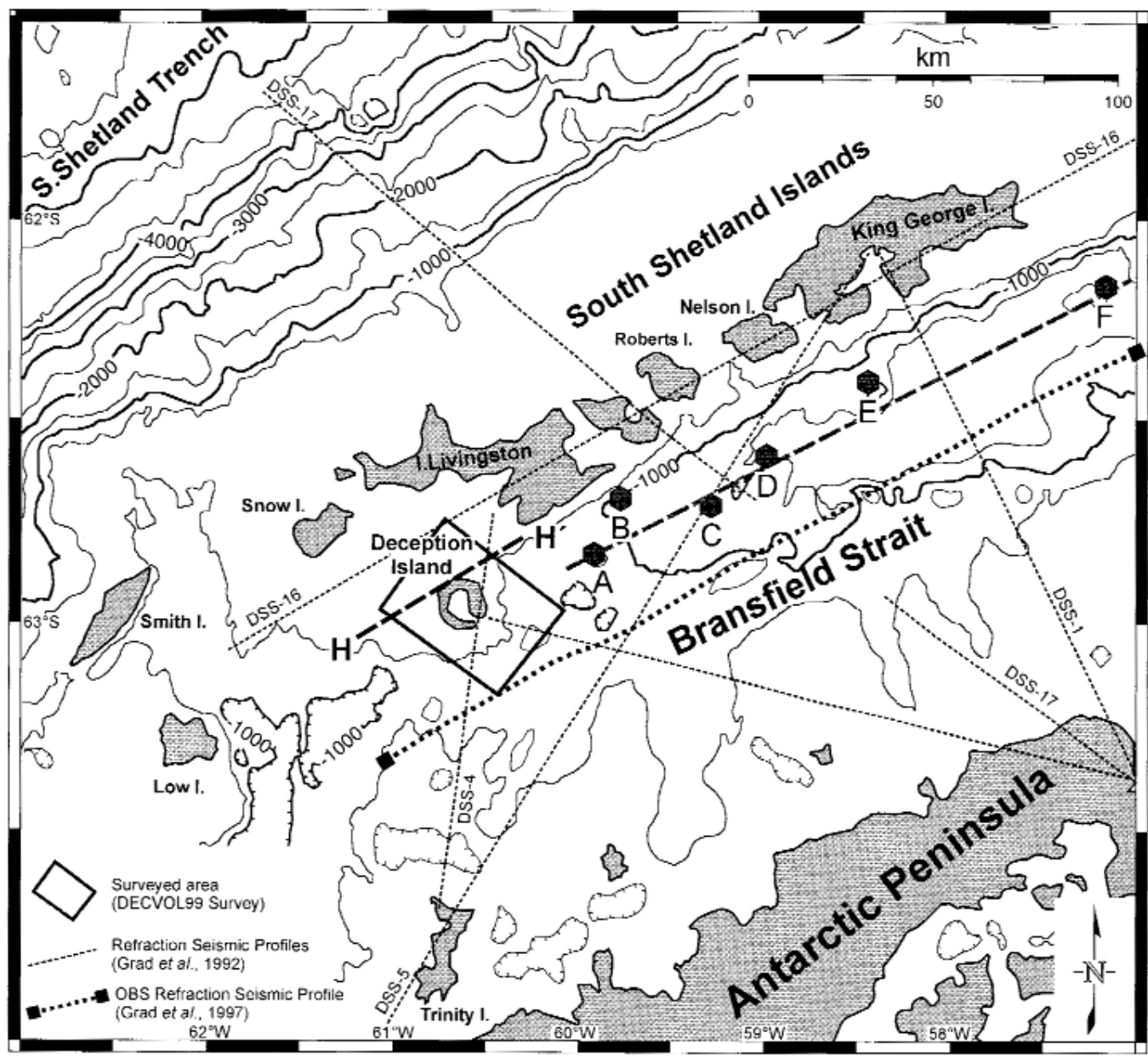

Fig. 2. Bransfield Strait bathymetric map. Seismic refraction profile lines are shown (Grad et al. 1992, 1997), as well as the surveyed area during DECVOL-99 marine geophysical cruise. Major volcanic lineaments $(\mathrm{A}-\mathrm{F})$ are included (modified from Gràcia et al. 1996).

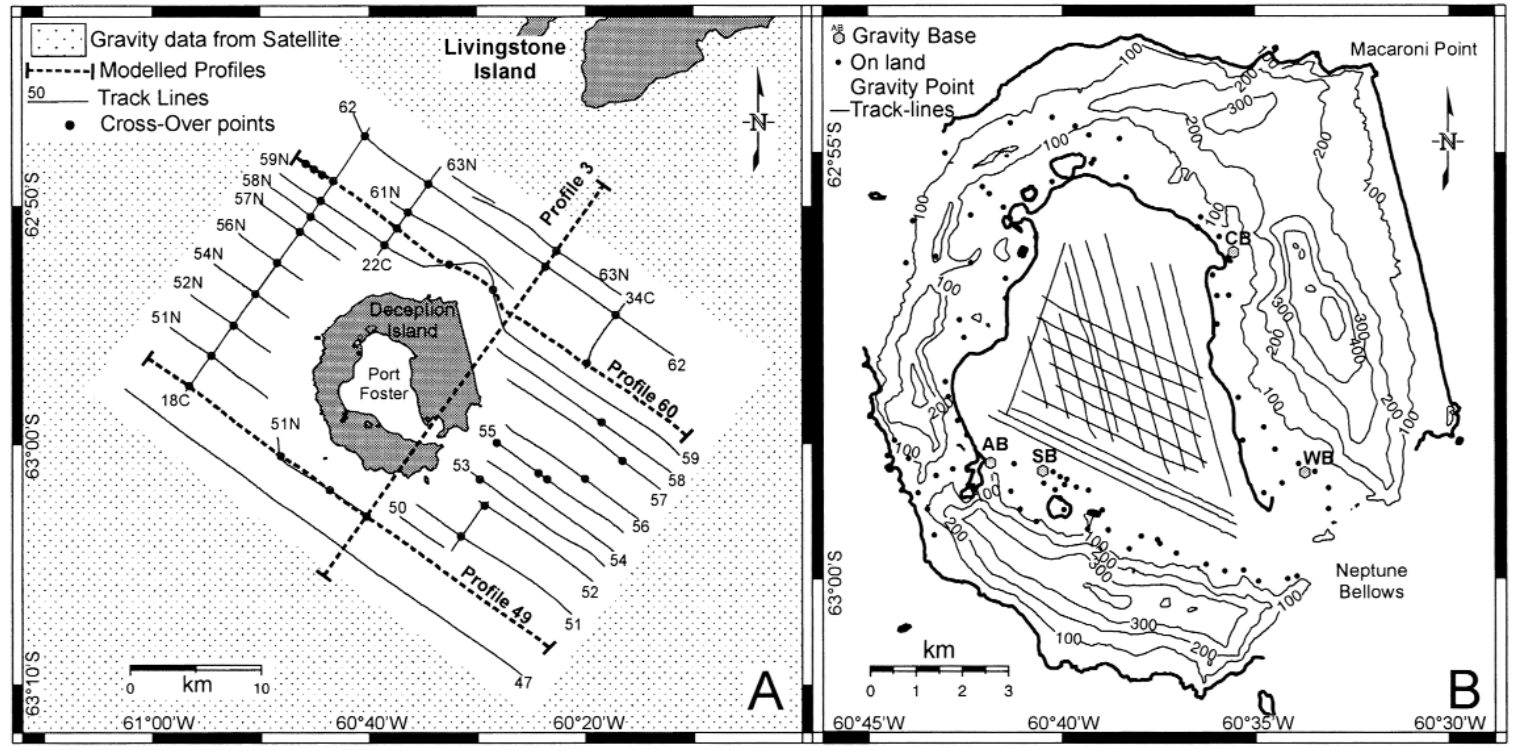

Fig. 3. Gravity and magnetic survey track lines performed at: a. outside and b. inside of Deception Island. Crossovers, used for the error budget estimation, are shown. $\mathrm{SB}=$ Gabriel de Castilla Base, $\mathrm{AB}=$ Argentinian station, $\mathrm{WB}=$ Whalers $\mathrm{Bay}$, $\mathrm{CB}=$ old $\mathrm{Chilean}$ station. 
the precision and internal consistency of our dataset, a crossover analysis was performed. This study was not only applied to the total survey as a whole but considered Port Foster (52 crossovers) and external Deception Island surroundings separately (77 crossovers) (Fig. 3). Results show a standard deviation of $0.36 \mathrm{mGal}$, and $1.65 \mathrm{mGal}$ as mean value for the internal grid, and $-0.46 \mathrm{mGal}$ and $2.6 \mathrm{mGal}$ for the external one. Both distributions show a normal distribution, and their standard deviation is below the marine gravimeter instrumental error level.

\section{Magnetic data processing}

In order to measure the geomagnetic field at sea, a Geometrics G-876 marine proton magnetometer, towed $200 \mathrm{~m}$ astern, was used with identical characteristics concerning track line peculiarities. Data sampling rate was $0.16 \mathrm{~Hz}$. To avoid trackiness, a $2000 \mathrm{~m}$ grid cell size was defined for the external survey, and a $250 \mathrm{~m}$ cell size was used for Port Foster. To prevent edge effects, we incorporated data from a complementary on-land survey developed around the Port Foster coastline: 95 points during DECVOL-99 campaign in December 1999, and 53 from GEODEC-MAR in January-February 2002. To remove the external component of the geomagnetic field, we used data from the Livingston Island geomagnetic observatory as well as those from an auxiliary reference station, installed at Deception Island. Marine data was affected by classical corrections: shift to sensor position and spike suppression. To extract the regular field contribution, we have used the IGRF2000 model (Mandea et al. 2000), referring measurement to epoch 2000.0. Following the same criteria as for gravity, we checked the quality of the external data set by using a crossover analysis. From a statistic based on 37 points we inferred a $8.5 \mathrm{nT}$ standard deviation, and a zero mean value. The statistical analysis for the Port Foster survey requires separate consideration. For this we performed a full levelling process, obtaining a crossover statistic similar to that at the external grid, that is $7 \mathrm{nT}$ as standard deviation and a zero mean value, from a set of 60 points. To improve the external grid spacing coverage, we included information from a previous geophysical cruise compiled by the Royal Observatory of the Spanish Navy (ROA) in collaboration with the Spanish Oceanographic Institute (IEO) during the 1991-92 summer. This survey was composed of 15 variable length track lines through the Deception Island northern margin, with $1800 \mathrm{~m}$ as an average across track distance. In order to improve spatial data coverage inside Deception Island, we used a pneumatic boat on the GEODEC-MAR campaign, with an Overhauser

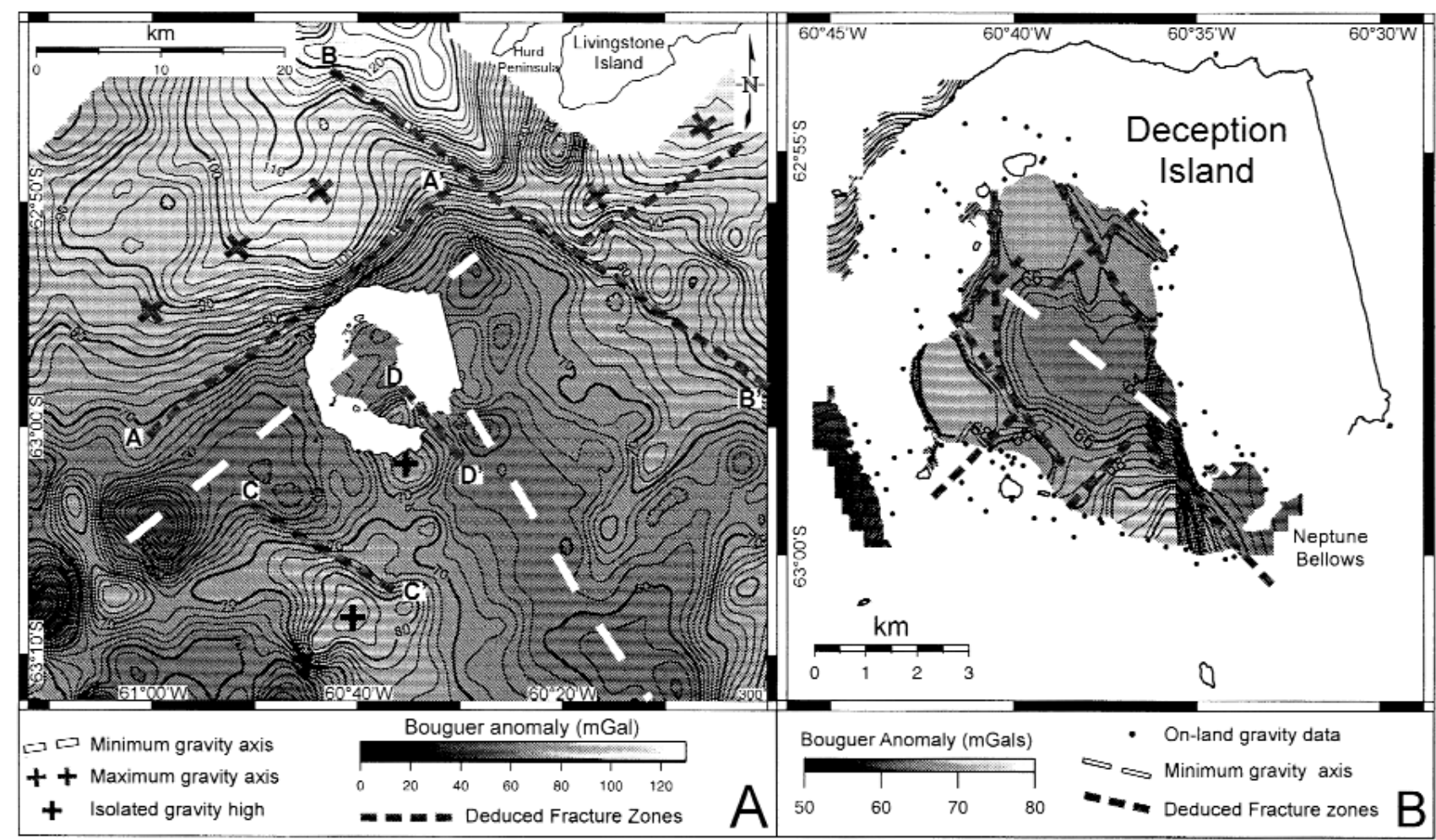

Fig. 4a. Bouguer gravity anomaly map in the Deception Island area, obtained from DECVOL-99 survey lines and land measurements (see Fig. 3). Gravity data derived from satellite altimetry has been incorporated to avoid edge effects (Smith \& Sandwell 1997). b. Bouguer gravity anomaly map of Deception Island inner bay (Port Foster), derived from marine and land measurements (Fig. 3b). See text for explanation. 
effect marine magnetometer (GEOMAG SMMII), towed $30 \mathrm{~m}$ astern and kept at sea-surface by a buoy. A portable GPS was used to position the boat, receiving differential corrections from a GPS station on land (Port Foster). The former track lines complement data coverage along the Deception Island southern margin, and the latter improved the link between magnetic marine data obtained during the DECVOL-99 cruise and magnetic readings on land. Magnetic anomalies from past campaigns (summer 1991-92) were referred to the epoch 1990.0. The DGRF90 was used as regular field model. We took into consideration that in order to minimize the impact of the secular variation coefficient error, the reference epoch must not be external to the period of validity of the regular field model (1990-95). Finally, we arbitrarily selected epoch 1990.0. In order to mix all these surveys, heterogeneous from the point of view of their error budget (secular variation contribution, instrumental precision, etc.) it was necessary to perform a previous levelling on DECVOL-99 track lines using a statistical tie line levelling technique. Accordingly, these surveys lines (from DECVOL-99) which intersect complementary surveys (summer 1991-92, GEODECMAR), were used as tie lines. Finally, a similar statistical levelling was performed, getting a global precision of $10.8 \mathrm{nT}$ for the whole track line set.

\section{Analysis of magnetic and Bouguer anomalies}

\section{Bouguer anomaly map}

This map (Fig. 4a) presents positive values, which increase from $40 \mathrm{mGal}$ (at the $\mathrm{SW}$ of Deception Island) to $120 \mathrm{mGal}$ in the surroundings of Livingston Island. Those values show the absence of well-defined oceanic crust (Talwani et al. 1965, Carbó et al. in press); the absence of oceanic crust was proposed in previous refraction seismic studies (Grad et al. 1997). Both maximum and minimum Bouguer anomalies mainly present two orientations:

a) a NE-SW direction, keeping parallel to the South Shetland archipelago alignment as well as the Bransfield Strait trend, and

b) a NW-SE direction, almost perpendicular to the previous one.

From the first group of anomalies, an elongated NE-SW maximum was singled out, which could be considered as the SW prolongation of Livingston Island crust. The amplitude of this anomaly decreases towards the SW. The southern limit of this anomaly is a high gradient area (labelled A-A', Fig. 4a) greater than $7 \mathrm{mGal} \mathrm{km}^{-1}$. This gradient was interpreted as an important fracture separating two types of crust, which were detected by previous refraction seismic works (Grad et al. 1992). According to some published works, the southern limit of the South



Fig. 5a. Scalar magnetic anomaly map of the study area. b. Scalar magnetic anomaly map of Deception Island bay (Port Foster) showing historical eruptions and thermal and fumarolic fields (modified from Ibáñez et al. 2000). 
Shetland archipelago has been defined by a set of NE-SW normal faults in easternmost sectors of the Bransfield Strait (Gràcia et al. 1996, 1997, Prieto et al. 1998). The NW-SE trending anomalies show a smaller wavelength. The most remarkable aspect is a minimum gravity band, located to the south-east of Deception Island, with a $20 \mathrm{~km}$ width on average, and relative amplitude between 10 and $20 \mathrm{mGal}$. This minimum anomaly is northerly limited by a high gradient area trending NW-SE (B-B', Fig. 4b) that presents a dextral apparent displacement of $10 \mathrm{~km}$. This gradient zone would coincide with a fracture area where two different crust types come into contact (Grad et al. 1992). Active normal faults at Livingston Island, according to upto-date structural information at Hurd Peninsula (Fig. 4a), are parallel to this NW-SE high gradient area (GonzálezCasado et al. 1999b). South of Deception Island a $10 \mathrm{~km}$ length maximum anomaly with a relative amplitude of $15 \mathrm{mGal}$ was found, that is northerly limited by a NW-SE high gradient zone, possibly correlated with a fracture zone (C-C', Fig. 4a). A similar arrangement (on a smaller scale) was found at the Deception Island inner bay (Port Foster, Fig. 4b). In this sense, the most remarkable feature is a NW-SE minimum axis, that is limited in the north and south by two maximum gravity anomalies. These two elongated sets of anomalies are crossed by a NE-SW minimum gravity axis that seem to be related to a highdensity pattern of submarine fractures in the northernmost part of Port Foster (Rey et al. 1995). This pattern of faults can also be found on land (González-Casado et al. 1999a). South of Deception Island, a local gravity maximum (15 mGal of amplitude, and about $8 \mathrm{~km}$ length) can be identified. It is constrained by high gradient zones trending to the NE-SW and NW-SE (Fig. 4a). This gravity maximum could be related to some high-density submarine volcanic domes on the southern side of Port Foster (Rey et al.1995). It is limited to the east by a high gravity gradient trending NW-SE, which runs through Neptune Bellows (D-D', Fig. 4a), and extends to the south-east of Deception Island. Taking into consideration its gravity characteristics, its magnetic signature (this area concentrates a one thousand $\mathrm{nT}$ range positive anomaly, Fig. 5), and previous refraction seismic information (Grad et al. 1992), we interpret it as an uplifted high-density block limited by two NW-SE and NE-SW fracture systems (Figs $4 \& 5$ ).

\section{Magnetic anomaly map}

On the magnetic anomalies map we observe a local maximum trending $\mathrm{NE}-\mathrm{SW}\left(\mathrm{H}-\mathrm{H}^{\prime}\right.$, Figs 2 \& 5a), which runs about $15 \mathrm{~km}$ north of the rest of volcanic edifices that lie along the Central Bransfield Basin (Fig. 2, Gràcia et al. 1997). This could be consistent with the dextral displacement seen in the NE-SW gravity gradient that marks the southern limit margin of the South Shetland archipelago (Fig. 4a, B-B'). Additionally, it correlates with a gravity minimum axis (Fig. 4a). The magnetic anomaly map of Port Foster indicates a dipolar shape for Deception Island (Fig 5b). Its north-eastern side concentrates negative magnetic values, with a smoother distribution than its south-western counterpart. This $2 \mathrm{~km}$ width negative anomaly area trends NW-SE, with local anomalies near the locations of the last eruptive episodes $(1967,1969,1970)$. The dipolar shape is locally interrupted northern of Fumarole Bay (FB), where a local minimum anomaly was found (Fig. 5b). Additionally, other local minimums could be identified in the surroundings of Telephone Bay (TB), in Whalers Bay (WB), and at Pendulum Cove (PC) as well as to the south of them. Those local minimum magnetic anomalies present a reasonable correlation with the position of thermal anomalies (López-Martínez et al. 1996), which are mainly concentrated on the coastline. Both areas (southwestern side positive anomalies and north-eastern side negative values) are separated in the inner bay by a high gradient signal that marks a NW-SE trend and reaches values of $1 \mathrm{nT} \mathrm{m}^{-1}$. Its location is correlated with a submarine volcanic axis (Rey et al. 1995).

Several authors have commented on the long wavelength minimum anomaly that runs all through the inner bay with a NW-SE trend. García et al. (1990) using spectral analysis criteria concluded that a high temperature linear intrusive

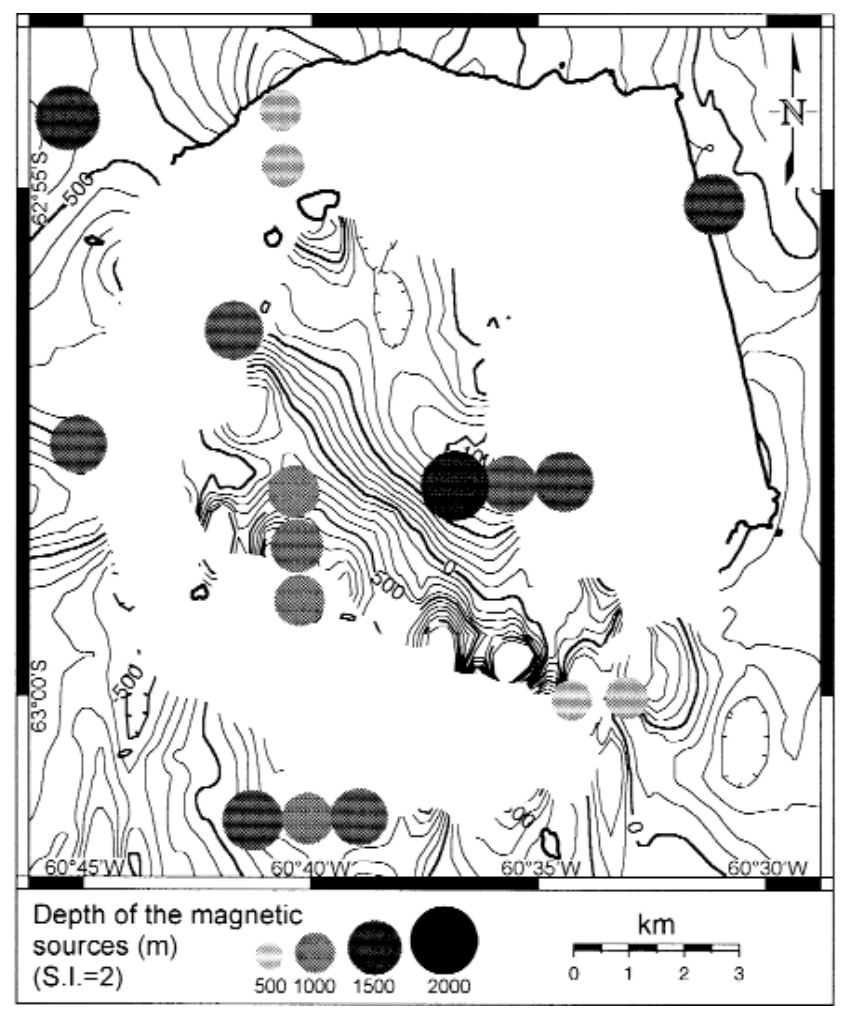

Fig. 6. Euler Deconvolution (structural index $=2$ ) depth estimation from magnetic data. The symbols size and depth of shading are proportional to the depth of the top of the magnetic source. See text for explanation. 
body should be positioned at a $2 \mathrm{~km}$ depth. Concerning its origin, Blanco (1997) proposed three alternatives. The first considers a topographic origin. This seems unlikely because this magnetic absolute minimum does not coincide with the deepest bathymetric area, situated to the north. A possible recent pyroclastic origin is also proposed for Port Foster. This is based on the fact that these deposits, from rock samples measured in the laboratory, present quite low bulk susceptibilities. This suggests a contrast of magnetization that could explain a strong magnitude negative anomaly. Nevertheless, this should affect the whole bay, and its linear shape also makes this quite unlikely. The final possibility concerns the presence of a magmatic reservoir with an original basaltic magma with an andesitic-type composition (García et al. 1990). Emeleus (1977) showed that for this composition there is a very rapid fall in thermo-remanent magnetization over a rather narrow temperature range $\left(200-400^{\circ} \mathrm{C}\right)$. Martini \& Giannini (1988) infer from thermodynamics considerations, and Ibáñez et al. (2000) indicated, that a temperature of $600^{\circ} \mathrm{C}$ could be reached at a
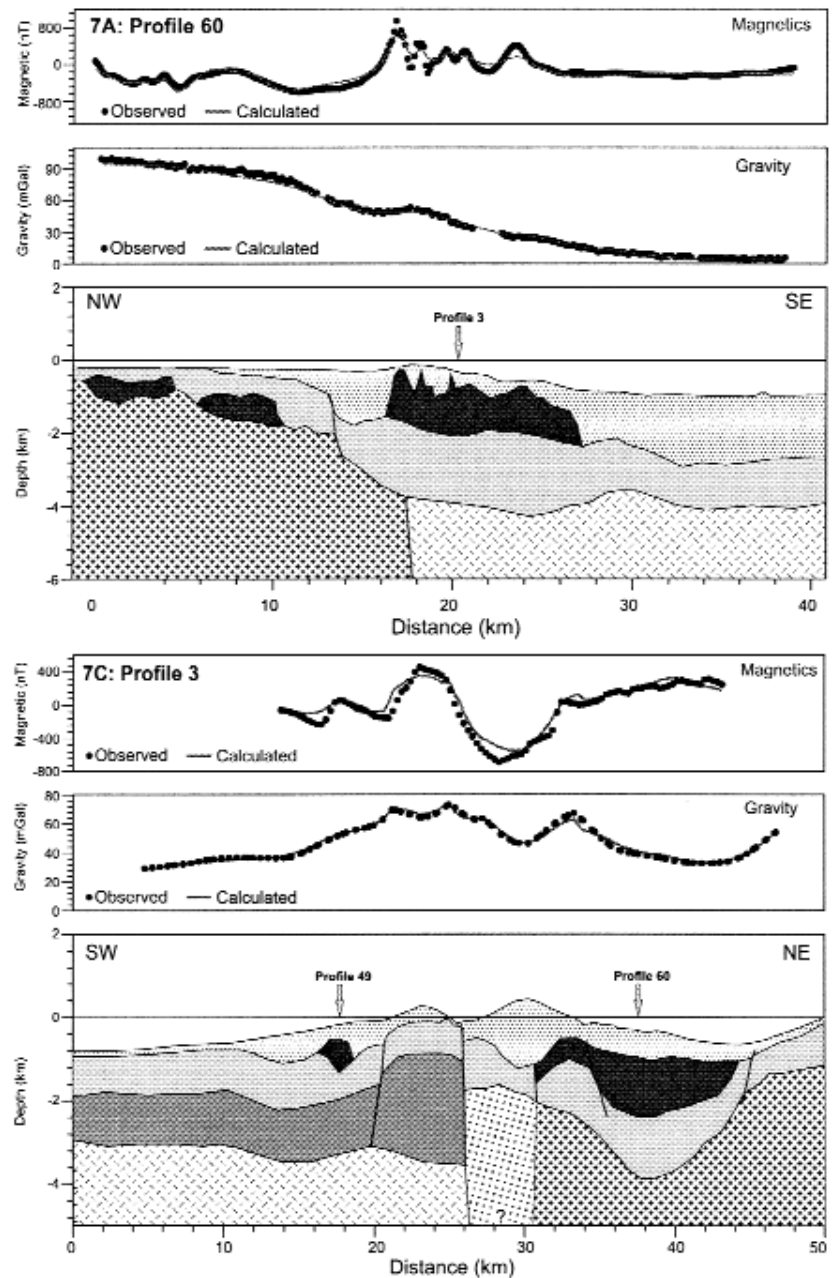

depth of just a few kilometres. Such high temperatures could cause an intrusive body to present horizontal differences in the 2000-3000 nT range, according to Emeleus (1977). We agree with García et al. (1990), who considered this to be the most plausible explanation for such a strong negative anomaly. The presence of many shallow aquifers has been documented by several authors (Martini \& Giannini 1988, Martí \& Baraldo 1990). Thus, a destruction or degradation of magnetic properties as a consequence of hydrothermal alteration is also possible, although some contribution from pyroclastic sediments could be plausible as well. Nevertheless we consider the latter a lower order effect.

\section{Euler deconvolution}

To aid later modelling we applied the Euler deconvolution algorithm (Thomson 1982, Reid et al. 1990) to the magnetic anomaly grid (Fig. 6). The Euler Eq. (1) relates the magnetic (or gravity) field and its gradients components to
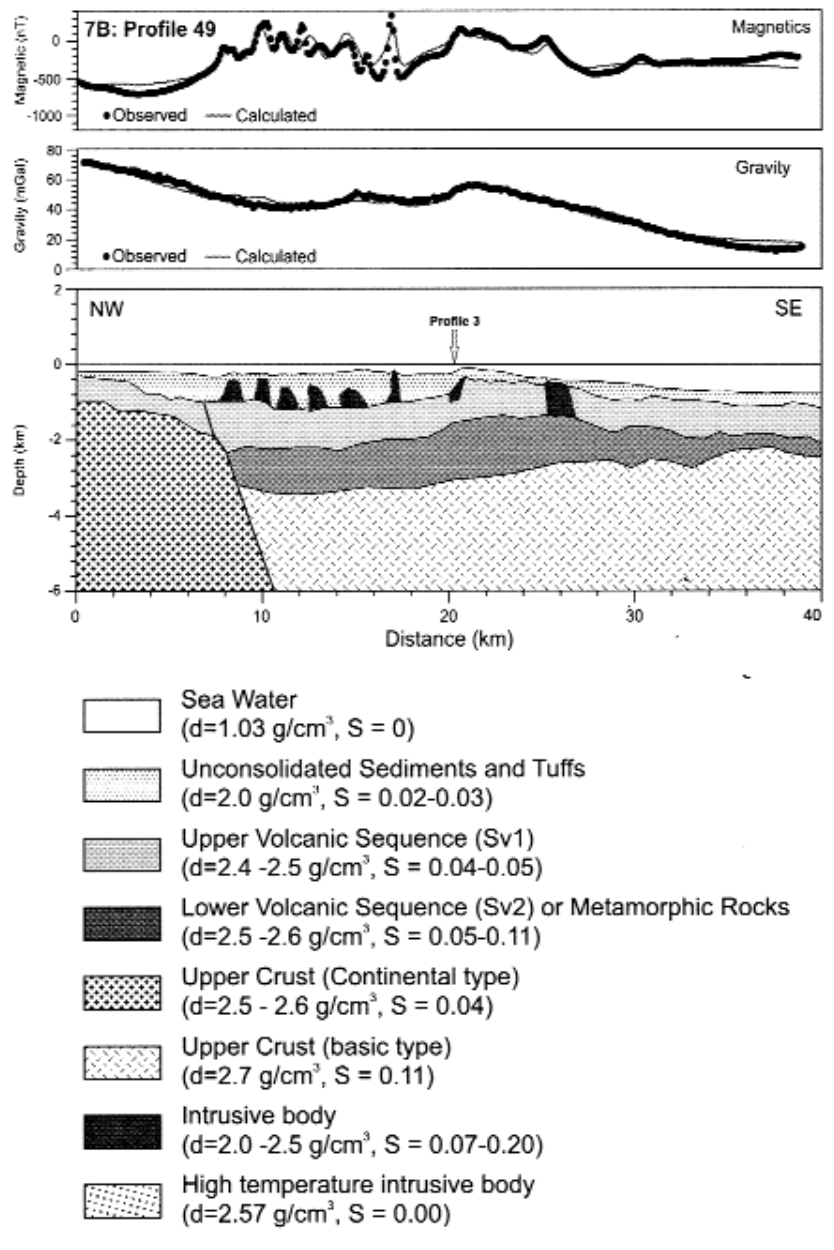

Fig. 7. Magnetic and Gravity models for a. profile 60, b. profile 49 and c. profile 3. Magnetic units $=$ nT. Gravity units $=$ mGals. Profile locations are shown in Fig. 3. 
Table I. Used parameters in the gravity and magnetic forward modelling.

\begin{tabular}{ccccl}
\hline Layer & Density $\left(\mathrm{g} \mathrm{cm}^{-3}\right)$ & $\mathrm{Vp}\left(\mathrm{km} \mathrm{s}^{-1}\right)^{*}$ & Susceptibility (IS) & Geological units \\
\hline 1 & 1.03 & 1.5 & 0 & sea water \\
2 & 2 & $1.9-2.2$ & $0.02-0.03$ & unconsolidated sediments and tuffs \\
3 & $2.4-2.5$ & $4.0-4.3$ & $0.04-0.05$ & upper volcanic sequence (consol. sediments and laves) [SV1] \\
& & & $0.05-0.11$ & lower volcanic sequences or metamorphic rocks [SV2] \\
4 & $2.5-2.6$ & $5.6-5.9$ & 0.04 & upper crust [continental type] \\
5 & 2.7 & $6.3-6.9$ & 0.11 & upper crust [basic type] \\
6 & $2.0-2.5$ & & $0.07-0.20$ & intrusive body \\
7 & 2.57 & & 0 & high temperature intrusive body \\
\hline
\end{tabular}

*Vp velocity values from Grad et al. 1992, 1997.

the location of the source with the degree of homogeneity $\mathrm{N}$, which may be interpreted as a structural index (SI) (Thompson 1982).

$$
\left(x-x_{0}\right) \frac{\partial T}{\partial x}+\left(y-y_{0}\right) \frac{\partial T}{\partial y}+\left(z-z_{0}\right) \frac{\partial T}{\partial z}=N(B-T)
$$

where $\left(\mathrm{x}_{0}, \mathrm{y}_{0}, \mathrm{z}_{0}\right)$ is the position of the magnetic source whose total field $\mathrm{T}$ is measured at $(\mathrm{x}, \mathrm{y}, \mathrm{z})$. The total field has a regional value of $\mathrm{B}$. The degree of homogeneity $(\mathrm{N})$ can be interpreted as a structural index (SI), which is a measure of the rate of change with distance of a potential field. For instance, in a magnetic field a narrow vertical dyke has a structural $=1$, while a vertical pipe gives $\mathrm{SI}=2$. Given a set of observed total field data, we can determine an optimum source location $\left(\mathrm{x}_{0}, \mathrm{y}_{0}, \mathrm{z}_{0}\right)$ by solving Euler's equation for a given SI by least-squares inversion of the data. The inversion process will also yield an uncertainty (standard deviation) for each of the fitted parameters, and this inversion process is called Euler deconvolution

Considering the spatial dimensions of the anomaly, we have checked high values for the structural index (2 and 3). A structural index $=2$ provides $1.7 \mathrm{~km}$ as the estimated depth to the top of the source, obtaining a solution of $2.5 \mathrm{~km}$ for structural index $=3$. We consider the former more realistic because the latter (structural index $=3$ ) corresponds to an ideal case (sphere source). Nevertheless both estimations are in the same order of magnitude proposed by García et al. (1990). The Euler deconvolution results were then plotted in plan view (Fig. 6) only for Port Foster.

\section{Gravity and magnetic modelling}

We have selected two NW-SE profiles, which correspond to track lines 60 and 49 (Fig. 3a), and that are perpendicular to the NE-SW structures detected by seismic refraction and to the main gradients on the Bouguer and magnetic anomaly maps (Figs $4 \& 5$ ). Finally, we have modelled a third profile perpendicular to the two previous tracks (Transect 3, Fig. 3) that is perpendicular to a fracture area detected by seismic refraction at Neptune Bellows (Grad et al. 1992). Gravity and magnetic models have been executed in $2+1 / 2 \mathrm{D}$ (Talwani \& Heirtzler 1964, Campbell 1983). For the gravity models we have used free-air anomaly values and assumed a lateral extent between 5 and $20 \mathrm{~km}$, which coincides with the distance between model location and the lateral borders of the anomalies. Seven different groups of materials have been considered on the basis of refraction data from Grad et al. (1992, 1997). Layer composition (density and bulk susceptibility) is shown in Table I, as well as the densityseismic velocity correspondence derived from empirical curves (Ludwig et al. 1970). The lower crust and mantle are not shown in the models, but they were modelled as horizontal layers at 19 and $30 \mathrm{~km}$ depth, respectively, as was pointed out by Grad et al. (1997) for the south-west part of Bransfield Strait. To constrain surface features, we used data from refraction and reflection seismic profiles in Deception Island, as well as the previously described petrological and structural data from Deception and Livingston islands (Smellie et al. 2002). Models have been first adjusted in zones with major seismic control and fewer uncertainties (extremes north-east and south-west of Deception Island), extending towards those areas where seismic data are scarce and the emerged part.

In the magnetic modelling, those sources that generate short wavelength anomalies have been considered intrusives. As we do not have additional information, their bottom has been located at the top of the consolidated sediments and tuffs layer, except in two cases at Profile 60, and one case at Profile 49, because sediment layer thickness is very thin. In these cases we preferred to use the upper crust (Profile 60) and the top of the lower volcanic sequence (SV2, Profile 49). All the above-mentioned reasons probably caused the susceptibility values to be higher than they would have been if these bodies had longer depth extensions and were situated at greater depths.

Concerning the remanent magnetization contribution, there is a lack of objective information to evaluate the intensity and direction of this vector, and it was considered more appropriate not to take this effect into account. Thus, bulk susceptibility values obtained during the modelling process should be considered as effective, merging both effects: induced and remanent magnetization. Considering that the age of the island is younger than $780 \mathrm{ka}$ (Baraldo \& Rinaldi 2000, Smellie 1988), and that the most recent 
polarity change, corresponding to the Brunhes-Matuyama boundary, was dated at about $760 \mathrm{ka}$ (Cande \& Kent 1995), it seems reasonable to expect that there is currently a similar polarity contribution due to remanent magnetization. The fact that magnetic anomalies are positive strongly supports the idea. All these reasons justified that bulk susceptibility values obtained through the modelling process should be greater than real ones for the intrusive sources. In the following paragraphs the models obtained from the forward modelling are analysed.

\section{Profile 60}

The gravity profile shows a widespread, non-homogeneous decrease from $100 \mathrm{mGal}$ to a nearly $5 \mathrm{mGal}$ value in its south-east part (Fig. 7a). It presents a strong gradient $(\mathrm{km} \mathrm{13})$ at the north of Deception Island. Two local shortwavelength low and high fluctuations $(<4 \mathrm{~km})$ follow it. Subsequently another high gradient area was discerned, giving way to a stable anomaly value $(5 \mathrm{mGal})$. The magnetic anomalies were grouped in three regions (Fig. 7a). The first one presents a $-340 \mathrm{nT}$ average value with three local maximums: two of them present a short wavelength signature, while the last shows an $8 \mathrm{~km}$ wavelength. At Deception Island surroundings ( $\mathrm{km} \mathrm{16)}$, and for $12 \mathrm{~km}$, a fast short wavelength sequence is delineated, possibly correlated with the volcanic characteristics of the environment. In the third region the anomaly reaches a negative average value of $-200 \mathrm{nT}$. This systematic difference between first and third part has been interpreted as a consequence of the existence of two crust types, which mainly differ in their magnetic properties and densities. From the forward modelling we estimate a bulk susceptibility contrast of 0.07 (IS) and a density contrast of $0.15 \mathrm{~g} \mathrm{~cm}^{-3}$ between the two crust types, with the uppermost values belonging to the south-east crustal block. These data are in agreement with previous seismic refraction works (Grad et al. 1992) that concluded that two tectonic units exist on either side of Deception Island: a crystalline basement and an altered one located at the southern part of Deception Island.

The starting points for gravity modelling were the refraction seismic models obtained for profiles DSS-19N and DSS-4N in the Grad et al. (1992) seismic data. These models show a fairly simple structure at north-east of Deception Island: a sediment layer, as well as a quite undeveloped upper volcanic sequence (thickness $<4 \mathrm{~km}$ ), on the top of a crystalline basement. Taking this information as a constraint, we progressed to the south-west in the forward modelling. The modelled upper crustal structure described a simple picture. In its north-west extreme, we found two unique levels below a thin water layer: an upper volcanic sequence (SV1), and an upper crust. The upper volcanic sequence increases its thickness to the south-east, with a small narrowing around $\mathrm{km} 13$ that could be caused by a discontinuity which lowered the top of the unit about $700 \mathrm{~m}$. This step could be attributed to a NE-SW normal fault. The change between these two types of crust has been modelled as a south-east tilted contact from $\mathrm{km} 17$.

\section{Profile 49}

It shows a widespread decrease in gravity values, from 74 $\mathrm{mGal}$ in the north-west region to a nearly $15 \mathrm{mGal}$ value in the south-east part (Fig. 7b). This general behaviour is locally interrupted by two short wavelength ( 3 and $5 \mathrm{~km}$ as wavelength) local highs located at 15 and $21 \mathrm{~km}$ from the beginning of the profile (Fig. 7b). Once again, the starting points for gravity modelling were the previous refraction seismic models (Grad et al. 1992), particularly its profiles DSS-19N and DSS-4N (south-west of Deception Island). The magnetic signature of Profile 49 shows a similar style to Profile 60. It shows two smooth regions separated by a sequence which is formed by short wavelength signals as well as fast spatial variation anomalous sources. We have proposed three levels under the water layer: recent sediments, upper volcanic sequence (SV1) and lower volcanic sequence (SV2). In the same way as suggested by Profile 60, we observe an increase in depth for the top of its upper crust towards the south-east.

An important discontinuity was detected at about $\mathrm{km} 8$, which has been interpreted as a fault. This limit marks a lowering in the top of the upper crust, as well as a slight increase in thickness for the recent sediment layer and SV1. This fault and the discontinuity suggested on Profile 60 ( $\mathrm{km} \mathrm{12)} \mathrm{seem} \mathrm{to} \mathrm{be} \mathrm{correlated.} \mathrm{The} \mathrm{NE-SW} \mathrm{high} \mathrm{gradient}$ area that appears in the Bouguer anomaly grid (A-A', Fig. 4) seems to reinforce this idea. From this fracture on to the south-east, both magnetic and gravity models suggest a change in crustal structure, which agrees with previous refraction seismic studies (Grad et al. 1992). Particular attention must be paid to a new layer modelled under the SV1. It has a $2.55 \mathrm{~g} \mathrm{~cm}^{-3}$ in density on average, and extends to the central part of Bransfield Strait. Considering its depth and density, this new layer must correspond to a lower volcanic sequence (SV2), as suggested by Grad et al. (1997). This unit has also been modelled in Profile 3. As it has been already noted for Profile 60, in the middle of the magnetic signature of Profile 49, we could discern two signals with a wavelength longer than $20 \mathrm{~km}$. The metamorphic character of SV2 unit has served to accommodate, throughout the modelling process, the greater variability concerning bulk susceptibility. The long wavelength positive magnetic anomaly (located at $\mathrm{km} \mathrm{22)}$ coincides with a gravity high. To take into account both effects, we have introduced an uplifted block because its magnetic as well as gravity characteristics seem more similar to the volcanic sequence layers (SV1 and SV2) than to the sediment layer. 


\section{Profile 3}

This was done to link the previous two models, and previous refraction seismic profiles determined its geographical position (Grad et al. 1992), allowing a gravity and seismic correlation to $6 \mathrm{~km}$ depth. This previously interpreted seismic section showed two different upper crust types located at the south and the north of Deception Island, respectively. Its boundary was established in a fracture zone just at Neptune Bellows (Fig. 3). Two nearly horizontal layers were detected on the south-west of Deception Island $\left(\mathrm{Vp}=5.7-5.9\right.$ and $\left.6.5 \mathrm{~km} \mathrm{~s}^{-1}\right)$. Nevertheless, in the northeast sector an inclined refractor, the top of the crystalline basement under the non-consolidated sediments, is progressively lifted up in a northward direction. The magnetic profile shape is simple (Fig. 7c). Only two signals could be discerned hanging on a small average value. The first one is a local maximum located to the south-west ,associated with an intrusive body. The second one shows a sinusoidal shape, interpreted as a consequence of the contrast of magnetization between western and eastern margins. Following Ortiz et al. (1992), we attribute this negative magnetization contrast as induced by the existence of a deep high temperature intrusive source. In the forward modelling process, we have assigned it a null bulk susceptibility, and fits in our model with a $2.57 \mathrm{~g} \mathrm{~cm}^{-3}$ as density. This block extends horizontally from kilometre 26 to 32 , and we have located its top at a $1.7 \mathrm{~km}$ depth, taking into account Euler deconvolution results (Fig. 6). Concerning its vertical extension, nothing could be inferred from our data.

The gravity profile (Fig. 7c) shows, from south-west to north-east, an increase in gravity anomaly values (from $30 \mathrm{mGal}$ to slightly greater than $70 \mathrm{mGal}$ at Deception Island), and a strong gradient area in the south-west corner of the island. A long wavelength local high marks the influence of the island. This signal incorporates two local highs and a low between them $(\mathrm{km} \mathrm{40)}$, which is related to the north-east caldera sector and shows a correlation with the minimum magnetic anomaly described before. Between the first high and the low, there is a strong gradient area with a NW-SE trend, located in the Neptune Bellows (labelled as D-D', Fig. 4a), that has been interpreted as a sub-vertical fault with a vertical displacement slightly smaller than $1000 \mathrm{~m}$. These data are in agreement with the DSS-4 seismic refraction profile (Grad et al. 1992).

From the forward modelling, the recent sediments layer (RS) becomes thicker to the north-east of Deception Island. In the same way, contacts between RS layer, the SV1, and the upper crust seem to be dipping towards the south-west, appearing to form what seems to be a non-emerging intrusive body located at the north-east corner of the island ( $\mathrm{km} \mathrm{34).} \mathrm{This} \mathrm{body} \mathrm{is} \mathrm{under} \mathrm{the} \mathrm{RS} \mathrm{layer,} \mathrm{has} \mathrm{a} 2.5 \mathrm{~g} \mathrm{~cm}^{-3}$ density, has a lateral extension of $4 \mathrm{~km}$ and has not been detected by seismic refraction. The profile ends with an important increase in gravity anomaly values through a high gradient area with a NW-SE trend (B-B', Fig. 4). We have interpreted it to be a sinistral strike-slip fault zone with a $15 \mathrm{~km}$ lateral displacement. This fault marks the contact between the continental upper crust of the Livingstone Island and the basic type upper crust located towards the central Bransfield Strait. Finally, the sedimentary sequence becomes thinner to the north where it ends fairly abruptly against a normal fault zone (South Shetland southern limit). This fault zone displays a thinning of the sediments.

\section{Discussion and conclusions}

Gravity and magnetic anomaly maps show different fractures and anomalous bodies in the surroundings of Deception Island. The Deception Island inner side gravity anomaly map has been presented and described with its magnetic counterpart. In order to objectively analyse the most relevant characteristics associated with main geophysical structures, both outside as well as inside Deception Island, two transverse profiles to these main structures and gradients have been modelled. Vertical layer structure has been inferred on the basis of seismic refraction data from Grad et al. (1992, 1997). To fulfil the crustal structure as well as to control the previous two profiles, a perpendicular transect that runs through Deception Island embayment was modelled. From the forward modelling we focussed special attention on: Two types of crust were detected, mainly set apart by their magnetic and density characteristics (a mean susceptibility contrast of 0.07 and a density contrast of $0.15 \mathrm{~g} \mathrm{~cm}^{-3}$ ), with greater values in the south-eastern crustal block. This possibility was proposed by Grad et al. (1992) from seismic refraction studies. This result would be compatible with a standard continental crust (located north of Deception Island) versus a more basic one (south of Deception Island). The transition between both crustal types is also detected in the Bouguer anomaly map as two high gradient areas trending NE-SW and NW-SE at the north of Deception Island, that we have interpreted as fracture zones (A-A' and B-B', Fig.4a). The first one adjusts to a normal fault in the gravity and magnetic models, and we interpret the second one as a NW-SE oblique fault with an apparent dextral displacement of $10 \mathrm{~km}$.

Both magnetic and gravity anomaly maps and Profile 3, show a wide minimum at the same geographical location (eastern Deception Island) which suggests a very low bulk susceptibility and low density intrusive body. The fact that historical dated eruptions and thermal and fumarolic fields show a reasonable spatial correlation with this minimum (Fig. 5), lead us to interpret this anomaly as a partially melted intrusive body. Its top has been estimated to be at $1.7 \mathrm{~km}$ depth by using Euler deconvolution techniques. The south-west limit of the melted body has been interpreted as a sub-vertical NW-SE fault, located near the Neptune Bellows (labelled as D-D', Fig. 4a). The vertical 
displacement calculated from gravity and magnetic models is slightly smaller than $1000 \mathrm{~m}$.

\section{Acknowledgements}

This research has been partially supported by the projects CICYT ANT99-1428-E and REN2000-0551-C03-03 ANT. The authors gratefully acknowledge the Spanish RV "Hespérides" crew, as well to the participants in DECVOL99 cruise, and to the "Unidad de Tecnologia Marina" for its technical support and collaboration. We also thank the referees, Peter Morris, Marek Grad and J.M. González, for their helpful comments on the original manuscript. Maps were drafted with Generic Mapping Tools software (Wessel $\&$ Smith 1998).

\section{References}

Acosta, J., Herranz, P., Sanz, J.L. \& Uchupi, E. 1992. Antarctic continental margin: geologic image of the Bransfield Trough, an incipient ocean basin. In POAG, C.W. \& GRACIANSKY, P.C., eds. Geologic evolution of Atlantic continental rises. New York: Van Nostrand Reinhold, 49-61.

BARALDO, A. \& RinALDI, R.A. 2000. Stratigraphy and structure of Deception Island, South Shetland Islands, Antarctica. Journal of South American Earth Sciences, 13, 785-796.

Barker, P.F., Dalziel, I.W.D. \& Storey, B.C. 1991. Tectonic development of the Scotia Arc region, In TINGEY, R.J., ed. Antarctic geology. Oxford: Oxford University Press, 215-248.

Barker, D.H.N. \& Austin, J.A. 1994. Crustal diapirism in Bransfield Strait, West Antarctica: evidence for distributed extension in marginalbasin formation. Geology, 22, 657-660.

Barker D.H.N., Christeson, G.L., Austin, J.A. \& Dalziel, I.W. 2003. Backarc basin evolution and Cordilleran orogenesis: insights from new ocean-bottom seismograph refraction profiling in Bransfield Strait, Antarctica. Geology, 31, 107-110.

Blanco, I. 1997. Análisis e interpretación de las anomalias magnéticas de tres calderas volcánicas: Decepción (Shetland del Sur, Antártida), Furnas (San Miguel, Azores) y las Cañadas del Teide (Tenerife, Lanzarote). PhD thesis, Universidad Complutense de Madrid, 250 pp. [Unpublished].

CAMPBELL, D.L. 1983. Basic programs to calculate gravity and magnetic anomalies for $2+1 / 2$ dimensional prismatic bodies. USGS Open-file report, 83-154.

CAnde, S.C. \& Kent, D.V. 1995. Revised calibration of the geomagnetic polarity timescale for the Late Cretaceous and Cenozoic. Journal of Geophysical Research, 100, 6093-6095.

Carbó, A., Muñoz Martín, A., Llanes, P., Álvarez, J. \& ZEE Working Group. In press. Gravity analysis offshore the Canary Islands from a systematic survey. Marine Geophysical Researches.

DALZIEL, I.W.D. 1984. Tectonic evolution of a fore-arc terrane, southern Scotia Ridge, Antarctica. Geological Society of America Special Papers, No. 200, 32 pp.

EMELEUS, T.G. 1977. Thermo-magnetic measurements as a possible tool in the prediction of volcanic activity in the volcanoes of the Rabaul Caldera, Papua New Guinea. Journal of Volcanology and Geothermal Research, 2, 343-359.

Engdahl, E.R., VAn Der List, R.D. \& Buland, B. 1998. Global teleseismic earthquake relocation with improved travel times and procedures for depth relocation. Bulletin of the Seismological Society of America, 88, 722-743.
García, A., Catalán, M., Rey, J., Vila, J. \& Viramonte, J.G. 1990. Anomalias magnéticas en Decepcion y su integración en el estudio del Mar de Scotia. Actas de la Primera Conferencia Latinoamericana sobre Geofisicica, Geodesia e Investigación Espacial Antárticas. Buenos Aires, Argentina: Publicacion del Centro Latino-Americano de Fisica (CLAF), $62-71$.

GARRETT, S.W. 1990. Interpretation of reconnaissance gravity and aeromagnetic surveys of the Antarctic Peninsula. Journal of Geophysical Research, 95, 6759-6777.

Giner-Robles, J.L., GonzÁlez-CAsado, J.M., Gumiel, P., Martín, S. \& GARCÍA, C. 2003. A kinematic model of the Scotia plate (SW Atlantic Ocean). Journal of South American Earth Sciences, 16, 179-191.

GonzÁlez-CAsado, J.M., López-Martínez, J., Giner, J., DurÁn, J.J. \& Gumiel, P. 1999a. Análisis de la microfracturación en la isla Decepción, Antártida Occidental. Geogaceta, 26, 31-34.

GonZÁlez-Casado, J.M., López-Martínez, J. \& DurÁn, J.J. 1999 b. Active tectonics and morphostructure at the northern margin of central Bransfield Basin, Hurd Peninsula, Livingston Island (South Shetland Islands). Antarctic Science, 11, 323-311.

González-Casado, J.M., Giner, J. \& López-Martínez, J. 2000. Bransfield Basin, Antarctic Peninsula: not a normal backarc basin. Geology, 28, 1043-1046.

Gràcia, E., Canals, M., Farràn, M., Prieto, M.J., Sorribas, J. \& Gebra TEAM. 1996. Morphostructure and evolution of the central and eastern Bransfield basins (NW Antarctic). Marine Geophysical Researches, 18, 429-448.

Gràcia, E., Canals, M., Farràn, M., Sorribas, J. \& Pallás, R. 1997. The central and eastern Bransfield basins (Antarctica) from highresolution swath-bathimetry data. Antarctic Science, 9, 168-180.

Grad, M., Guterch, A. \& Sroda, P. 1992. Upper crustal structure of Deception Island area, Bransfield Strait, West Antarctica. Antarctic Science, 4, 469-476.

Grad, M., Shiobara, H., Janik, T., Guterch, A. \& Shimamura, H. 1997. Crustal model of the Bransfield Rift, West Antarctica, from detailed OBS refraction experiments. Geophysical Journal International, 130, 506-518.

IbáÑez, J.M., Del Pezzo, E., Almendros, J., Larocca, M., Alguacil, G., OrtiZ, R. \& GARCíA, A. 2000. Seismovolcanic signals at Deception Island volcano, Antarctica: wave field analysis and source modelling. Journal of Geophysical Research, 105, 13 905-13 931.

LAwVER, L.A., Keller, R.A., Fisk, M.R. \& Strelin, J.A. 1995. Bransfield Basin, Antarctic Peninsula: active extension behind a dead arc. In TAYLOR, B., ed. Backarc basins: tectonic and magmatism. Plenum Press: Amsterdam, 315-342.

Lawver, L.A., Sloan, B.J., Barker, D.H.N., Ghidella, M., Von HerZaen, R.P., Keller, R.A., KlinkHammer, G.P. \& Chin, C.S. 1996. Distributed, active extension in Bransfield Basin, Antarctic Peninsula: evidence from multibeam batymetry. GSA Today, 6-11, 1-6.

Livermore, R., Balanya, J.C., Maldonado, A., Martinez, J.M., Rodríguez, J., Sanz de Galdeano, C., Galindo, J., Jabaloy, A., Barnolas, A., Somoza, L., Hernandez, J., Surinach, E. \& Viseras, C. 2000. Autopsy on a dead spreading center: the Phoenix Ridge, Drake Passage, Antarctica. Geology, 28, 607-610.

López-Martínez, J., Ramos J., Criado, C., Serrano, C. \& Nicolás, P. 1996. Anomalías geotérmicas y permafrost en la Isla Decepción, Antártida, Actas del V symposium español de estudios antárticos. Madrid: Comisión Interministerial de Ciencia y Tecnología (CICyT), 223-234.

Ludwig, W.J., Nafe, J.E. \& Drake, C.L. 1970. Seismic refraction. In MaXwell, A.E., ed. The sea, vol. 4. New York: Wiley-Interscience, 53-84.

Maldonado, A., Larter, R.D. \& Aldaya, F. 1994. Forearc tectonic evolution of the South Shetland margin, Antarctic Peninsula. Tectonics, 13, 1345-1370. 
Mandea, M., MacMillan, S., Bondar, S., Golovkov, V., Lanlais, B., Lowes, F., Olsen, N., Quinn, J. \& SABAKa, T. 2000. International geomagnetic reference field - 2000. Physics of the Earth and Planetary Interiors, 120, 39-42.

Martini M. \& GianNini, L. 1988. Deception Island (South Shetlands): an area of active volcanism in Antarctica. Memorie Società Geologica Italiana, 43, 117-122.

Martí J. \& BARALDO, A. 1990. Pre-caldera pyroclastic deposits of Deception Island (South Shetland Islands). Antarctic Science, 2, 345-352.

Ortiz, R., Vila, J., García, A., Camacho, A.G., Díez-Gil, J.L., Aparicio, A., Soto, R. \& Viramonte, J.G. 1992. Geophysical features of Deception. In Yoshida, Y., Kaminuma, K. \& Shiraishi, K., eds. Recent progress in Antarctic earth sciences. Tokyo: Terra Scientific Publishing Company, 443-448.

Pelayo, A.M. \& Wiens, D.A. 1989. Seismotectonics and relative plate motions in the Scotia Sea Region. Journal of Geophysical Research, 94, 7293-7320.

Prieto, M.J., Canals, M., Ercilla, G. \& Batist, M. 1998. Structure and geodynamic evolution of the Central Bransfield Basin (NW Antarctica) from seismic reflection data. Marine Geology, 149, 17-38.

Reid, A.B., Allsop, J.M., Granser, H., Millet, A.J. \& Somerton, I.W. 1990. Magnetic interpretation in three dimensions using Euler deconvolution, Geophysics, 45, 80-91.

Rey, J., Somoza, L. \& Martínez-Frías, J. 1995. Tectonic, volcanic and hydrothermal event sequence on Deception Island (Antarctica). GeoMarine Letters, 15, 1-8.
RoACH, P.J. 1978. The nature of backarc extension in Bransfield Strait. Royal Astronomical Society Geophysical Journal, 53, 165.

Smellie, J.L., Pankhurst, R.J., Thomson, M.R.A. \& Davies, R.E.S. 1984. The geology of South Shetland Islands: VI. stratigraphy, geochemistry and evolution. British Antarctic Survey Scientific Reports, No. 87, 85 pp.

Smellie, J.L. 1988. Recent observations on the volcanic history of Deception Island, South Shetland Islands. British Antarctic Survey Bulletin, No. 81, 83-85.

Smellie J.L., López-Martínez J., Headland R.K., HernandezCifuentes F., Maestro A., Millar I.L., Rey J., Serrano E., Somoza L., Thomson J.W. \& Thomson, M.R.A. 2002. Geology and geomorphology of Deception Island. BAS GEOMAP Series, Sheet 6-a and 6-b, 1:25.000, with supplementary text. Cambridge: British Antarctic Survey, 77 pp, 3 sheets.

SMITH, W.H.F. \& SANDWELL, D.T. 1997. Global seafloor topography from satellite altimetry and ship depth soundings. Science, 277, 1956-1962.

TALWANI, M. \& HEIRTZLER, J.R. 1964. Computation of magnetic anomalies caused by two-dimensional structures of arbitary shape. In PARKES, G.A., ed. Computers in the mineral industries. Stanford, CA: University Publications, Geological Sciences, Vol. 9, 464-480.

Talwani, M., Le Pichon, X. \& Ewing, M. 1965. Crustal structure of the mid-ocean ridges 2 . Computed from gravity and seismic refraction data. Journal Geophysical Research, 70, 341-352.

THOMSON, D.T. 1982. EULDPH: a new technique for making computerassisted depth estimates from magnetic data. Geophysics, 47, 31-37.

Wessel, P. \& Sмith, W.H.F. 1998. New, improved version of the Generic Mapping Tools release. Eos, Transactions of the American Geophysical Union, 79, 579. 